\title{
RESOURCE USE EFFICIENCY AMONG BENEFICIARIES AND NON BENEFICIARIES OF A RURAL, DEVELOPMENT PROJECT IN NIGERIA
}

\author{
IMONIKHE G. A. AND CHIKWENDU D. O. \\ National Fadama Development Project. Wuse 11 Abuja. Nigeria.
}

\begin{abstract}
This study was conducted to assess the benefits of the Katsina State Agricultural and Community Development Project (KSACDP) on income of project and non-project beneficiaries. Data were obtained from 460 selected project and non-project farmers 230 each) in 15 Local Government Areas (LGAs) of Katsina State. The Cobb Douglas production function was best fitted and was employed in data analysis. The result of the siudy shows a high efficiency ratio for land, hired labour, fertilizer, seeds and pesticides in the project area. This implies that increase in the use of these factors would result in a correspondent increase in output of project farmers. However, the efficiency ratio of land, hired labour, fertilizer, seed, and pesticides in the non-project areas were low. An increase in the use of these inpuls would likely result in a decrease in output of the farmers.

The study revealed that farmers prefer mixed cropping to sole cropping which could be a security against crop failure. Various sizes of farm lands were cultivated. The lowest hectares cultivated $(0.8$ and 0.5 hectares) and the highest land cultivated was 6.5 and 4.2 hectares in the project and nonproject areas respectively. The variations in size of individual farms in the two areas could be due to varying socio-economic factors such as level of education, access to inputs and credit facilities.

The total farm incomes were N42,776,.96, and N 36,932.95 per hectare of each crop in the project and non-project areas respectively while the total costs of production in both areas were N22, 336.84 and N19,881.55 per hectare of each crop respectively. The net farm income for both areas was $N$ $20,140.12$ and $N 17.051 .41$ per hecture of each crop respectively. It could be concluded that project and non project beneficiaries break-even in the ir farming activities.
\end{abstract}

\section{KEY WORDS: Rural Development Project, Beneficiaries.}

\section{INTRODUC'TION}

Since independence, agriculture has been the most important economic sector in terms of its contributions to the Gross Domestic Product, Adegeye (1993). The sector contributes about $41 \%$ of the countries GDP, cmploys about $65 \%$ of the total population and provides employment to about $80 \%$ of the rural population. Abdullahi (1986). Available statistics show that total food production increased from 54.76 million grain cquivalent in 1997 to 57.70 million grain equivalent in 2001 . Akinyemi (1998). Agricultural growth rates increased modestly from 4.25\% in 1997 to $4.5 \%$ in $1999.4 .7 \%$ in 2001 and $7 \%$ in 2004, Central Bank of Nigeria (CBN. 2005).

Food production in Nigeria mostly depended on the small-scale farmers who are often characterised by the use of unimproved farm implements and traditional production tools that are capable of generating only very small income to farmers. Dittoh (1992). The low income of the farmers leads to low levels of savings and investment. and low investment consequently leads to low productivity and income, Mohammed. (1990). In response to the problem of Agricultural sector and rural development, the Katsina State Agriculture and Community Development Project (KSACDP) commenced activities in 1994. The project had an initial lifespan of eight years but was reviewed to six years during the Mid-lerm Review. However, because of delay in start-up and to ensure that project objectives are achieved. International Fund for Agriultural Development (IFAD) approved an extension of loan closing date to June 31.2001.

The project objective was aimed at improving the living standard of the rural poor and 
Agrosererch 20005$) 7$ Vo. 1

deprived families especially households headed by women, by increasing their agricultural production. income, food security and investing in community development in the villages. This was to be achieved through participatory process, technical support, assistance in natural resource management. on-farm and off-farm activities, group mobilisation for credit and savings, access to services and joint action for community development. The specific objectives of the project include:

(i) Halting resource degradation in critical areas of Katsina State and repair as far as it is practicable, possible damage done in order to recover land for productive agriculture;

(ii) Increasing the production, income and food security and nutritional status of poor households through land conservation, crop yields improvement, provision of credit, improved input supply and better uses of fadama lands;

(iii) Generating greater participation of beneficiaries in the long-term development of their communities by supporting the state and Local Governments to provide more responsive and effective services:

(iv) Inculcating the habit and capabilities to plan. finanee and manage their own programme of development in the communities: and

(v) Evolving sustainable project design and management approach which places reliance on local effort and on private sector involvement.

Pursuant to the above listed objectives, the project area covers 23 villages spread in 15 Local Government Arcas (I.GAs) of the State.

\section{Problem Statement}

The small-scale farmer has been the major producer of food and cash crops in Nigeria. Due to urbanisation and rapid growth in population. the agricultural sector has not been able to cope with the increasing demands made on it. This has led to massive importation of various food items and raw materials to augment this shortage in supply. Also, relative cheaper imports and terms of trade have progressively worsened for the small-scale farmers since they use very limited capital inputs as compared to their foreign competitors (Akinyosoye; Adeyeye, 1993).

There has been persistent concern on the northern drought-prone parts of Katsina state bordering Niger Republic, which is poor, arid and marginal for agriculture but densely populated. This has led to the implementation of the Katsina State Agricultural and Community Development Project (KSACDP) to help achieve the expected increase in farmers' productivity and income generation. However, since the completion of KSACDP in 2001, very little attempt has been made to study the impact of the project on farm income and productivity of the targeted beneficiaries. There is also a dearth of input-output data on the use of modern inputs and their effect on productivity in the area.

The huge capital investment that the Federal and State Governments have committed to agricultural production and development especially the KSACDP justifies an in-depth study of the impact of this project on farmer's income and productivity of the beneficiary communities.

The broad objective of the study is to determine the resource use efficiency of project and non-project farmers while the specific objectives are to:

i) describe the socio-economic characteristics of the respondents:

ii) assess input used by project and non-project beneficiaries and;

iii) calculate the resource use efficiency of project beneficiaries and non beneficiaries.

\section{Methodology}

The Katsina State Agricultural and Community Development Project was implemented in 15 Northern Local Government Areas of Katsina state which include: Zongo (Sara). Daura (Modobi), Mashi (Goro), Bindawa (Doro), Sandamu (Rade), Dutsi (Danaunai), Ingawa (Dara), Mani (Muduru), Kaita (Dankama), Jibia (Kusa), Rimi (Gobir), Mai'áduwa (Galadimawa), 
Batagarawa (Jino), Charanchi (Banye) and Baure (Dankum), which span some $8,400 \mathrm{~km}^{2}$ with a population of 2.6 million (Erhabor.1990).

The KSACDP Monitoring and Evaluation Unit in conjunction with the Projects Coordinating Unit (PCU) had conducted a Village Listing Survey in the project area in 1991. The survey covered fifteen (15) Local Government Areas (LGAs) of the state. Twenty three (23) villages were randomly selected from the fifteen LGAs that participated in the project and this constituted the village sample frame. Similarly, 23 non-benefiting villages were also randomly selected from the lifteen I.GAs that participated in the project. In each of the twenty three (23) villages, 10 bencliting and 10 non-benefiting farm families were randomly selected from the village sample frame. A total of four hundred and sixty farming families comprising of 230 benefiting and 230 nonbeneliting farm families were selected for the study. Household heads were used as respondents bccause of their decision making roles.

\section{Data collection}

Data were collected through the use of detailed structured questionnaire and interview schedule. Tiwo sets of questionnaire (same content) were administered; one to the project beneficiaries and the other to the non-project beneficiaries. Secondary data were also collected to supplement primary data. Sources of secondary data include; Appraisal report of International finds for Agricultural Development (IFAD) and World Bank reports, K $\Lambda$ SCDP Mid-Term reports. Socio-economic data collected include sex, age, educational level, family size and sources and amount of non-farm income realised annually.

Also, data were collected on types of crops grown (millet, sorghum and cowpea), yield per hectare, and total yicld obtained for the year. Data on cropping pattern, family and non-family labour (man hours), quantity of seed planted, total number of hectares devoted to crops, agrochemicals etc. lor cach of these variables, market prices were collected from the respondents.

\section{Analytical tool}

The Production function analysis was employed in the study.

Three functional forms linear, Cobb-Douglas (double log) and semi log were fitted.

the implicit form of the function is:

$$
\mathrm{Y} I\left(\mathrm{X}_{1}, \mathrm{X}_{2}, \mathrm{X}_{i}, \mathrm{X}_{4}, \mathrm{X}_{4}, \mathrm{U}\right)
$$

Where:

$\mathrm{Y}=$ Output (Kg grain equivalent)

$X_{1} \quad$ Land(ha)

$\mathrm{X}_{2}=$ I abour (man hours)

$X_{i}=$ Fertilizer $(\mathrm{kg})$.

$X_{4} \quad \operatorname{Secd}(k g$ grain cquivalent).

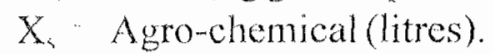

$U$ Errorterm.

The output of crops which were measured in kilogrammes $(\mathrm{kg})$ were adjusted to kilogram grain equivalents for homogeneity and output aggregation (Olayemi, 1991).

\section{Resource use efficiency}

Efficieny ratio ( $\mathrm{r}-\mathrm{MVP} / \mathrm{Ml} \mathrm{C}$ ) was calculated to determine the relative efficiency of resource use: Where,

MVP - Marginal Value Product

MFC Margina Fixed Cost 


\section{r Efficiency ratio.}

Where,

MVP is given as MPP. Py where MPP is the Marginal Phy sical Product, py is price per unit of output

If $\mathrm{r} \quad-1$ resource is efficiently used

If $\mathrm{r}>1$, resource is under utilised

If $\mathrm{r}<1$, resource is over utilised.

\section{Results and Discussion}

In traditional agriculture, the size of family is important because, it influences the supply of labour for immediate farm employment (Akinyemi. 2000). The study revealed that majority of the female respondents were Moslems and are in puddah. It was therefore difficult for them to take active part in farming operations except processing and marketing of farm products and caring for children. According to Norman (1983) in a rural Hausa land, women labour was found to be less than one percent while the average family size was 11 and 10 persons in the project and non-project area respectively (Table 1). Also, the average male and female was 4 and 5 persons and 3 and 2 persons respectively.

Table 1: Average persons per Household for the Project and Non project areas.

\begin{tabular}{|l|c|c|}
\hline \multirow{2}{*}{$\begin{array}{l}\text { Variable } \\
\text { Specification }\end{array}$} & $\begin{array}{l}\text { Project Area } \\
\text { Average No. of } \\
\text { Persons }\end{array}$ & $\begin{array}{l}\text { Average No. } \\
\text { Persons }\end{array}$ \\
\hline Male Adults & 4 & 5 \\
Female Adults & 3 & 2 \\
Children & 4 & 4 \\
Total & 11 & 10 \\
\hline
\end{tabular}

Source: Survey Data, 2002

The age of farmers to a certain extent affect their managerial ability (Erinle, 1990). Farmers learn by experience and observation. The more years a farmer spends on the farm, the better is his understanding of the economic, social and climatic factors that affect farming. The age distribution and sex of the respondents in the study areas are summarised in Table 2 . The study revealed that youths within the ages of 20-30 years contributed 36 percent of the total labour supply while the elderly group contributed 21 percent of the total labour output in the non-project area. 
Table 2: Age Distribution of project and Non-Project Beneficiaries

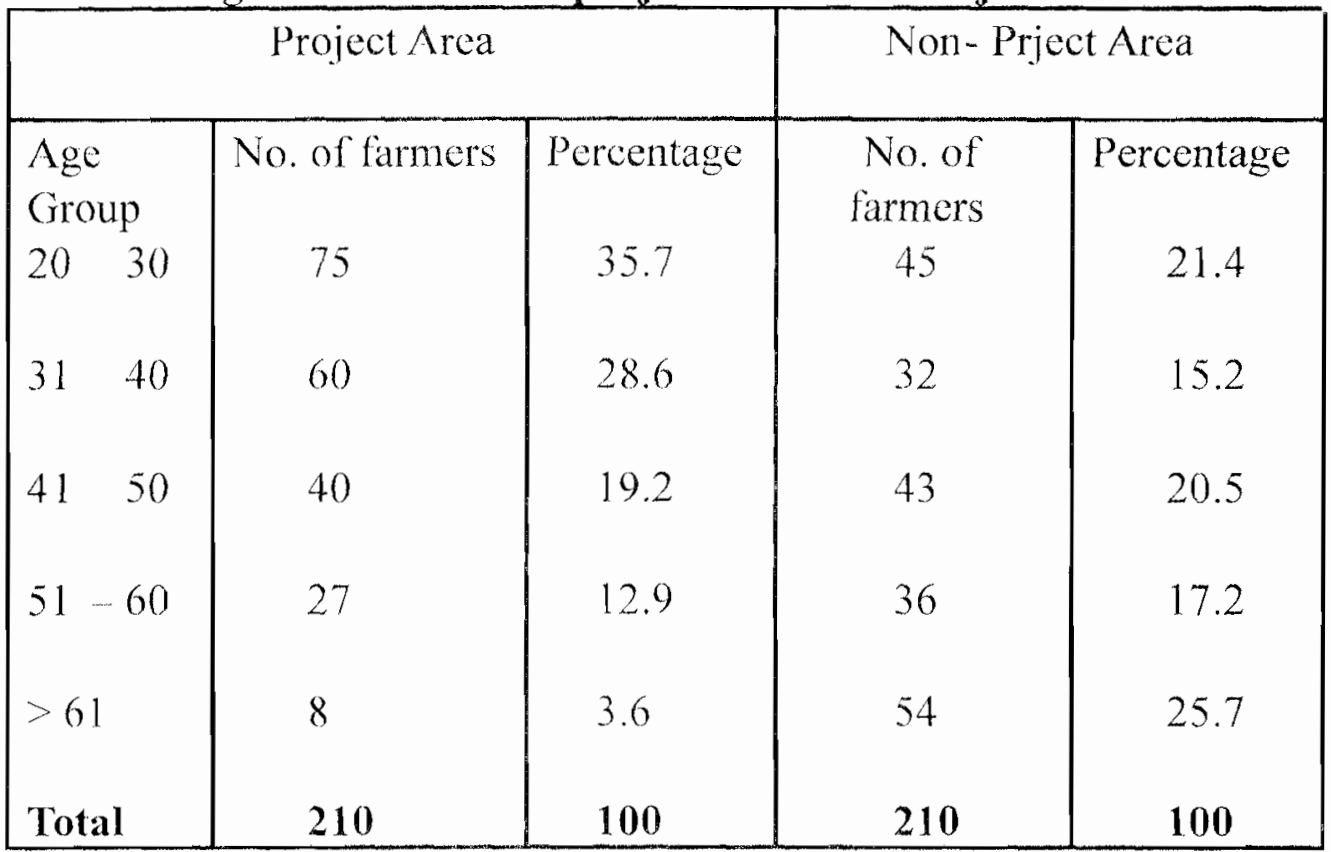

Source: Survey data, 2002

Table 3 shows the frequency distribution and farm sizes of respondents. The average size of land cultivated by rarious households in the project and non-project area was 2.5 and 3.2 hectares respectively.

Table 3: Distribution of Respondents Based on Farm Sizes in the Project and Non- Project Areas.

\begin{tabular}{|c|c|c|c|c|c|c|}
\hline \multicolumn{4}{|c|}{ Project Area } & \multicolumn{3}{|c|}{ Non Project Area } \\
\hline $\begin{array}{l}\text { Size by } \\
\text { Category } \\
\text { (Hectare) }\end{array}$ & $\begin{array}{c}\text { No. of } \\
\text { Respondents }\end{array}$ & $\begin{array}{c}\text { Average size of } \\
\text { Holding }\end{array}$ & $\begin{array}{c}\% \text { of total } \\
\text { Respondents }\end{array}$ & $\begin{array}{l}\text { No. of } \\
\text { Respond } \\
\text { ents. }\end{array}$ & $\begin{array}{c}\text { Average size of } \\
\text { Holding }\end{array}$ & $\begin{array}{c}\% \text { of total } \\
\text { Respondents }\end{array}$ \\
\hline $0.0-1.0$ & 45 & 0.8 & 21.4 & 64 & 0.5 & 30.5 \\
\hline $1.1-2.0$ & 40 & 2.0 & 19.2 & 48 & 2.0 & 22.9 \\
\hline $2.1-3.0$ & 35 & 2.5 & 16.6 & 35 & 2.5 & 16.7 \\
\hline $3.1-4.0$ & 30 & 3.0 & $1+.3$ & 26 & 3.2 & 12.4 \\
\hline+1.5 .0 & 35 & 6.5 & 16.6 & 23 & 4.2 & 10.8 \\
\hline $\begin{array}{l}>5.1 \\
\text { Total }\end{array}$ & $\begin{array}{l}25 \\
210\end{array}$ & $\begin{array}{l}3.0 \\
2.5\end{array}$ & $\begin{array}{l}11.9 \\
100\end{array}$ & $\begin{array}{l}14 \\
210\end{array}$ & $\begin{array}{l}6.2 \\
3.2\end{array}$ & $\begin{array}{l}6.7 \\
100\end{array}$ \\
\hline
\end{tabular}

Source: Survey Data 2002 
The study also shows that the lowest farm land cultivated by santpled farmers was 0.8 and 0.5 hectares in the project and non-project areas respectively while the highest farm land cultivated in the project and non-project areas were 6.5 and 4.2 hectares respectively. The variations in size of individual farms in the two areas could be due to varying socio-economic factors such as level of education, access to inputs and credit facilities.

The CobbDouglas production function regression coefficients represent the elasticities of production of the respective inputs and their sum indicates returns to scale, Erinle (1990). The study revealed that the sums of the regression coefficients for the project and non-project beneficiaries were estimated at 0.85 and 1.75 over the life of the project respectively. The sums of the coefficieces indicated that the project farmers exhibited an increasing return to scale while the non-project area exhibited decreasing returns to scale. The elasticity of seeds was calculated to be 0.270 . This means that a 100 percent increase in the use of these inputs would result in 27 percent increase in output of project farmers.

The results of the regression are shown in Tables $4(a)$ and 4 (b). The calculated adjusted coefficient of multiple detcrminations $\left(\mathrm{R}^{2}\right)$ was estimated to be 0.658 and 0.618 for the project and non-project areas respectively. This means that 65 and 61 percent of the observed variations in output in the study area were explained by all the variables indicated in the power function. The unexplained part of the variability could be due to other exogeneous factors such as drought, erosion, managerial ability that were not included in the model. The F-values were significant at five percent level of probability. Thus, explaining that the independent variables included in the model were important in explaining the variations in the dependent variable.

The result further revealed that land and hired labour were significant at 5 percent while Pesticides. seeds and fertiliser were significant at 10 percent level respectively. Similarly, in the nonproject area, land and family labour were significant at 10 percent while fertilizer, seed and pesticides were significant at $5 \%$ level respectively. This could be due to availability of cheap labour. and farmers relying on their last year's stock of seeds. Increased use of these factors of production would result in higher output and consequently a higher level of farm income to the farmers.

Table 4 (a): Results of the Cobb-Douglass Production Function

Analysis for the Project Beneficiaries

\begin{tabular}{|l|l|l|l|}
\hline Variable & Coefficient & $\begin{array}{l}\text { Standard } \\
\text { Error }\end{array}$ & t-Value \\
\hline Land & $1.322^{* *}$ & 0.65 & 2.04 \\
Family Labour & $0.512^{* *}$ & 0.136 & 3.77 \\
Fertilizer & $0.186^{*}$ & 0.177 & 1.05 \\
Seed & $0.270^{*}$ & 0.183 & 1.48 \\
Pesticides & $0.323^{*}$ & 0.210 & 1.54 \\
Constant & & 0.393 & \\
$\mathrm{R}^{2}$ & 0.780 & & \\
R & 0.658 & & \\
F-Value & $56.723^{* *}$ & & \\
\hline
\end{tabular}

Source: Survey Data, 2002.

** Significant at 5 percent level

* Significant at 10 percent level 
Table 4(b): Results of Cobb-Douglas Production Function Analysis

\begin{tabular}{|l|l|l|l|} 
for Non-Project Beneficiaries \\
Variable & Coefficient & $\begin{array}{l}\text { Standard } \\
\text { Error }\end{array}$ & t-Value \\
Fertilizer & 0.430 & 0.419 & 1.03 \\
Family labour & $0.750^{* *}$ & 0.349 & 2.15 \\
Seed & 0.601 & 0.458 & 1.312 \\
Pesticides & $0.528^{* *}$ & 0.152 & 3.473 \\
Constant & $0.738^{* *}$ & 0.332 & 2.23 \\
R & & 0.332 & \\
R & 0.732 & & \\
F-Value & 0.618 & & \\
\hline
\end{tabular}

Source: Survey data, 2002.

** Significănt at 5 percent level

* Significart at 10 percent level

The Cobb Douglas production function on the pooled data indicates that 66 and 62 percent of the variation in output was explained by the variable input included in production model in project and non-project areas respectively. The multiple determinations of 0.780 and 0.732 were calculated for project and non-project areas respectively while the adjusted coefficients of multiple determinations were 0.658 and 0.618 for the project and non-project areas. The F-statistics explained the behaviour of pooled factors of production and indicates the relationship between input and output of project and non-project farmers.

\section{Resource use efficiency}

The resource-use efficiency obtained from the study revealed that efficiency ratio of land, hired labour. fertilizer. seed and pesticide was greater than 1, implying that these factors of production were under utilised in the project area. An increase in the use of these factors of production would result in a correspondent increase in output respectively. Similarly, the efficiency ratio of land. hired labour. fertilizer, seed and pesticide in the non-project area was less than 1 . implying that these factors of production were over utilised. An increase in the use of these factors of production would result in a correspondent decrease in output respectively. The project farmers were producing at an increasing rate while the non-project farmers produced at a decrasing rate.

Table 5(a): Efficiency Ratios of Resource Use for Sorghum, Millet and Cowpea of the Project Beneficiaries

\begin{tabular}{|l|l|l|l|l|l|}
$\begin{array}{l}\text { Items } \\
\text { Estimated } \\
\text { MVP }\end{array}$ & Land & $\begin{array}{l}\text { Hired } \\
\text { Labour }\end{array}$ & Fertilizer & Seed & Pesticide \\
MFC & 870.80 & 184.80 & 372.40 & 378.00 & 172.20 \\
R & 750.00 & 120.00 & 750.00 & 120.00 & 130.00 \\
& 1.16 & 1.54 & 1.49 & 3.15 & 1.32
\end{tabular}

Source: Survey Data, 2002. 
Average rental value of one hectare of land in the two areas (Project and Non-project) was used as the unit factor cost of land (N750.00 and N400.00 per season) for every hectare of land.

Table 5(b): Efficiency Ratios of Resource Use for Sorghum, Millet, and Cowpea of Non - Project Beneficiaries

\begin{tabular}{|c|l|l|l|l|l|}
\hline Items Estimated & Land & $\begin{array}{l}\text { Family } \\
\text { Labour }\end{array}$ & Fertilizer & Seed & Pesticide \\
\hline MVP ( & 481.20 & 360.00 & 58.80 & 25.20 & 33.60 \\
MFC (丹) & 498.00 & 450.00 & 65.20 & 32.40 & 38.50 \\
R & 0.94 & 0.75 & 0.91 & 0.77 & 0.87 \\
\hline
\end{tabular}

Source: Survey Data, 2002.

\section{Credit facilities}

The study revealed that project and non-project farmers had access to credit facilities during project implementation. The average credit facilities received by the project and non-project farmers were N976,200.00 (61\%) and N616,500.00 (39\%) respectively as shown in Table 6 . These figures were subjected to statistical test and found that the calculated Z-value (2.70) was higher than the tabulated $Z$-value (1.96). Thus, it was concluded that the average credit received by the project farmers was significally higher than that of the non-project farmers. The data revealed that sources of credit include; project funds, commercial banks, friends/relatives, private money lenders and others.

Table 6: Distribution of respondents based on credit use.

\begin{tabular}{|l|c|c|c|c|c|c|c|c|}
\hline Sources & $\begin{array}{c}\text { Project Area } \\
\text { Responde } \\
\text { nts who } \\
\text { borrowed. }\end{array}$ & $\begin{array}{c}\text { Rate of } \\
\text { Interest } \\
(\%)\end{array}$ & $\begin{array}{c}\text { Total Amt. } \\
\text { Borrowed } \\
\text { (Naira) }\end{array}$ & $\begin{array}{c}\text { Percentage of } \\
\text { Respondents }\end{array}$ & $\begin{array}{c}\text { No. of } \\
\text { Respondents } \\
\text { who } \\
\text { borrowed. }\end{array}$ & $\begin{array}{c}\text { Rate of } \\
\text { Interest } \\
(\%)\end{array}$ & $\begin{array}{c}\text { Total Amt. } \\
\text { Borrowed } \\
\text { (Naira) }\end{array}$ & $\begin{array}{c}\text { Percentage of } \\
\text { Respondents }\end{array}$ \\
$\begin{array}{l}\text { Project } \\
\text { (ACDP) }\end{array}$ & 195 & 5 & 819,000 & 83.9 & - & - & - & \\
$\begin{array}{l}\text { Comm. Banks } \\
\text { Relatives' }\end{array}$ & - & - & - & - & 35 & 21 & 283,000 & 45.9 \\
$\begin{array}{l}\text { Friends } \\
\text { Private } \\
\text { money } \\
\text { lenders } \\
\text { Total }\end{array}$ & 3 & 35 & 78,000 & 8.0 & 135 & 15 & 164,000 & 26.6 \\
\hline
\end{tabular}

Source: Survey Data, 2002.

The costs and returns position of the sampled farmers by various crop enterprises, namely sorghum, cowpea and millet are shown in Table 7. The differences in farm sizes in different areas, the cost and returns analysis are standardised in terms of per unit of land area in hectares. The study revealed that the total farm incomes were $\mathrm{N} 42,476, .96$ and $\mathrm{N} 36,932.95$ per hectare of each crop in 
the project and non-project areas respectively while the total cost of production in both areas were N22, 336.84 and N19,881.55 per hectare of each crop respectively. The net farm income for both areas was $\mathrm{N} 20,140.12$ and $\mathrm{N} 17.051 .41$ per hectare of each crop respectively.

The study revealed that sorghum and millet utilized more labour when compared to cowpea in both areas. 'This could be due to cheaper sources of credit for hired labour on their farms. This compared favourably with a similar study carried out in ten demonstration farms in Kano, Ingawa (1983).

On enterprise basis, an average of $\mathrm{N} 2,591.00$ and N4, 195.50 of fertilizer was applied to sorghum N3, 680.00 and N3, 535.50 millet while N1, 720.50 and N1,005.00 worth of fertilizer was also applied to cowpea per hectare, in the project and non-project areas respectively. The high cost incured on fertilizer in the non-project area could be due to higher prices they had to pay for inputs at the open markets. The average cost of agro-chemicals per hectare in the project and non-project area was N1,614.09 and N1,228.80 respectively. The high cost of agro-chemicals in the project area could be due to the fact that farmers had to protect cowpea flowers from insects for proper fruiting and good yield. 


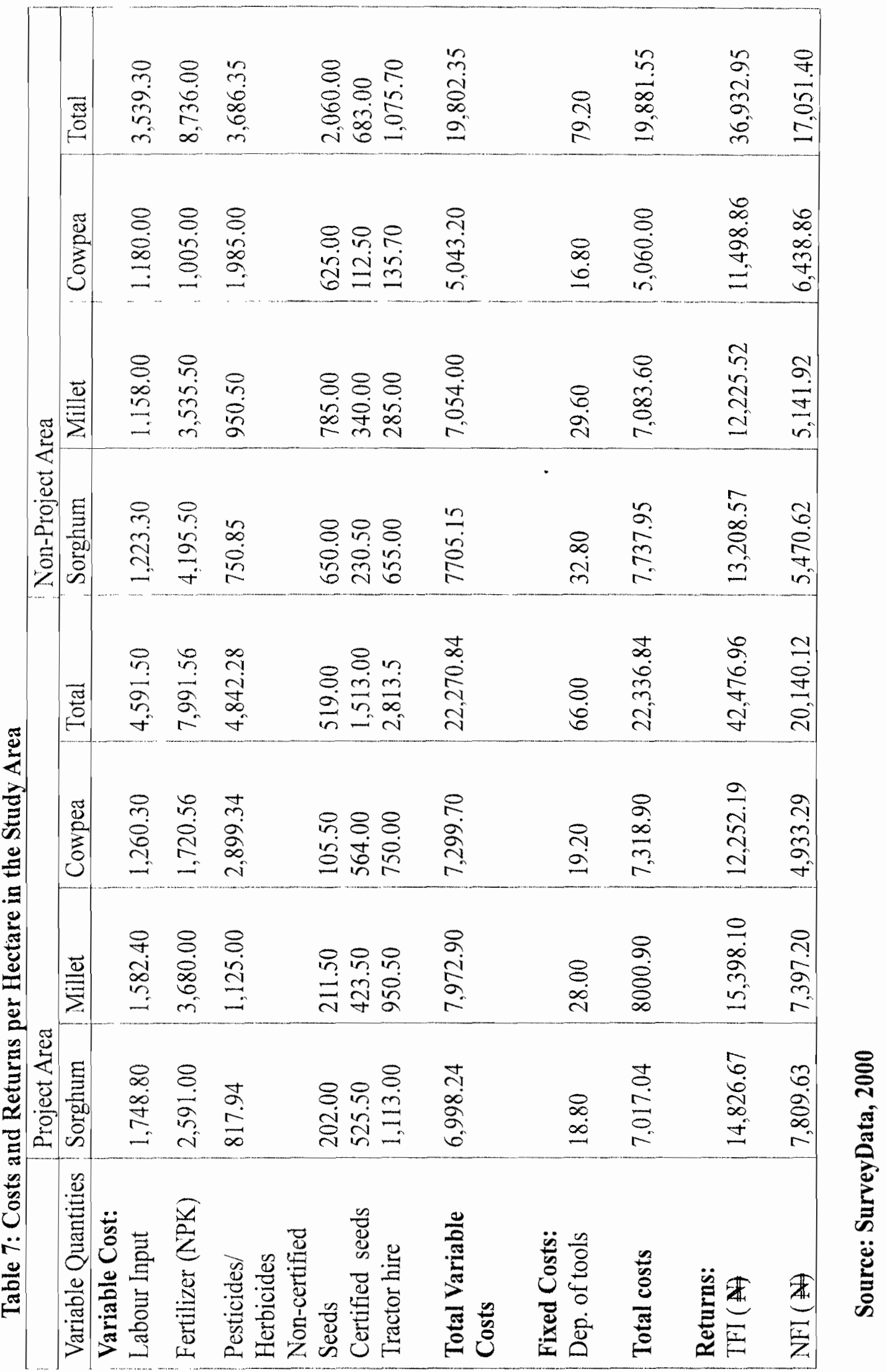




\section{Conclusion}

This study revealed that women respondents were Moslems and confined to puddah. They could not take active part in farming operations except processing and marketing of farm products and caring for children. The average family size was 11 and 10 persons in the project and non-project arca respectively

The study revealed that various sizes of lands were cultivated by farmers. The variations in size of individual farms in the project and non project areas could be due to varying socio-economic factors such as level of education, access to inputs and credit facilities. The study revealed the sums of regression coefficients for project and non-project farmers respectively while the elasticity of seeds was calculated. This means that an increase in the use of these input would result in a correspondent increase in output of project farmers. The adjusted coefficient of multiple determinations $\left(\mathrm{R}^{2}\right)$ was estimated for the project and non-project areas respectively. This implies that observed variations in output in both areas were explained by all the variables included in the power function. The unexplained part of the variability could be due to other factors such as drought, crosion, managerial ability that were not included in the model. The F-values therefore explained that the independent variables included in the model were important in explaining the variations in the dependent variable. The study showned that project farmers received credit facilities amounting N976.200.00 (61\%) while the non-project farmers received N616.500.00(39\%) Increased access to credit facilities and other forms of subsidy assisted both farmers to increase their production. Some of the farm produce were consumed while the surplus were either sold or preserve for the next farming season as foundation stock. The farmers were engaged in other olf-farm income generating activities such as trading, artisanship and processing of farm producc.

' the result of the study further show that land and hired labour were significant at 5 percent while pesticides, seeds and fertiliser were also significant at 1 percent level in the project area respectively. Similarly, land and hired labour were significant at 5 percent while fertilizer, seed and pesticides were significant at $1 \%$ level in the non-project area respectively. Ihis could be due to availability of fallow lands, cheap hired labour and farmers relied on their last year's stock of seeds.

The non project Carmers' incured high expenses on fertilizer application than the project farmers. This may be adduced to the fact that non-project farmers purchase these inputs from the open market while the project farmers purchase fertilizer from Government Service Centres. The costs of agro-chemicals per hectare in the project and non-project area was N1, 614.09 and $\mathrm{N} 1,228.80$ respectively. The high cost may be due to the fact that farmers had to protect cowpea flowers with pesticides inorder to achieve good fruiting and high yield.

The study revealed total farm incomes of N42,476,96, N 36,932.95 per hectare of each crop in the project and non-project areas and total costs of production in both areas were N22, 336.84 and N19,881.55 per hectare of each crop respectively. The net farm income for both areas was $\mathrm{N}$ $20,140.12$ and $N 17,051.41$ per hectare of each crop respectively. We conclude that both farmers made profit from every naira spent on the farm.

\section{Suggestions}

In view of the lindings of this study, the following suggestions are put forward:-

In designing agricultural development projects in Nigeria, special focus should be made on income distribution as an operational planning strategy to redistribute farm incomes in favour of small-scale farmers.

Government should encourage farmers to organise cooperative societies and credit groups to be able to assess credit facilities from commercial banks and credit institutions in Nigeria.

It is also suggested that similar studies could be conducted on the impact of the project on welfare of individual farmers especially as it relates to farmers' ability to save. respond to incentives and adoption of improve production techniques. 


\section{REFERENCES}

Adegeye, A. J. (1993). Economic Growth and Social Equity in Developing Countries.

California: Stanford University Press. 53-65

Abdullahi, Y.A. (1986). "Agricultural Development in Nigeria: Major Theoretical and Practical Questions". Lecture presented at the National Institute for Policy and Strategic Studies (NIPSS), Kuru, Jos. No 8. 14- 19.

Akinyemi. S. D (1998). "Economic Evaluation of the Impact of Oyo State Agricultural Development Project on Resource Use and Productivity of Farmers. A paper presented at the department of Agricultural Economics, University of Ibadan, Ibadan, Nigeria.

Akinyosoye. V.O. (1993). Redistribution with Growth, New York: Oxford University Press.

Akinyemi, S.D (2000). Economics of Irrigation Farming in Nigeria: “The Journey so far": A paper delivered at the National workshop on farmer participation in development and management organised by Institute for Agricultural Research, Ahmadu Bello University, and Zaria.

Central Bank of Nigeria, Annual progress Report 2005

Dittoh. S.A. (1992). "Priorities for Nigerian Agriculture in the $5^{\text {th }}$ National Development Plan 1986-1990". Paper presented at Conference on Strategies for the $5^{\text {th }}$ National Development, at the Nigeria Institute for Social and Economic Research (NISER), Ibadan.

Erinle, S.B. (1990)."The Present Status and Prospects for Increased Production of Tomato and Pepper in Northern Nigeria." Proceedings of the International Symposium on Integrated farming.

Erhabor, P.O. (1990). "Economics of Irrigation Farming in Nigeria: The Journey so far". A paper delivered at the National workshop on farmer participation in development and management organised by Institute for Agricultural Research, Ahmadu Bello University, Zaria.

Mohammed, G. I. (1990). "Economics viability of Wheat Production in Nigeria". The case of Kano River Project Farmers In Wheat in Nigeria: Production, Processing and Utilization, by A.J.Rayar, B.A.Kaigama,J.O.Olukosi and A.B. Anaso published by LCRI, IAR, UNIMAID, Maiduguri, Nigeria.pg

Norman, D.W. (1983). Labour input of Farmers: A case study of the Zaria Province of Nigeria. Samaru Research Bulletin, No.116.

Olayemi, J. K. (1991). "Inter-year Variation in the Level and Distribution of Income among Farmers in Omu-Aran Area of Kwara State". Samaru, Miscellaneous Paper No 115, IAR, ABU, Zaria. 